\title{
Foot mucus and periostracum fraction as non-destructive source of DNA in the land snail Arianta arbustorum, and the development of new microsatellite loci
}

\author{
G.F.J. Armbruster ${ }^{1} *$, B. Koller ${ }^{2}$ \& B. Baur ${ }^{1}$ \\ ${ }^{1}$ Department of Integrative Biology, Section of Conservation Biology, University of Basel, St Johanns- \\ Vorstadt 10, CH-4056 Basel; \\ ${ }^{2}$ ECOGENICS GmbH, Wagistrasse 23, CH-8952 Schlieren, Switzerland (*Corresponding author: Phone: \\ 004161 2670857; Fax: 004161 2670832; E-mail: g.armbruster@unibas.ch)
}

Received 15 June 2004; accepted 26 July 2004

Key words: DNA isolation, fingerprinting, gastropods, non-invasive genetics

Feathers, hair, egg membranes, bones, urine and faeces have all been utilized as non-invasive sources of DNA in vertebrate studies (e.g., Taberlet and Luikart 1999; Alpers et al. 2003; Idaghdour et al. 2003; Wisely et al. 2004; Hedmark et al. 2004). In insects, exuviae and caterpillar frass can serve as non-destructive DNA source (Feinstein 2004). Similar non-invasive sources of DNA are not yet available for endangered and rare molluscs. In this note, we report on two novel, nondestructive methods of DNA isolation in the land snail Arianta arbustorum (L.), and present nine novel microsatellite loci since previously published loci yielded a complete lack of heterozygosity (Locher and Baur 2001).

A conspicuous property of the gastropod integument is its facility to produce abundant amounts of mucus and proteineous fluid (Luchtel and Deyrup-Olsen 2001). Mucus is essential for locomotion. Copious mucus secretion can also deter attacks of invertebrate predators. We collected mucus samples by smoothly rubbing a 1-ml plastic tip on the foot of living A. arbustorum. In order to increase yield of genomic DNA, foot rubbing was repeated after $10 \mathrm{~min}$ using a second 1-ml plastic tip. Both tips were put together, and were incubated for $10 \mathrm{~min}$ at $70^{\circ} \mathrm{C}$ in $200 \mathrm{ml}$ of ATL buffer (DNeasy Tissue Kit, Cat. No. 69506; QIAGEN 2003) followed by a proteinase $\mathrm{K}$ digestion at $55^{\circ} \mathrm{C}$ and buffer and spin column treatment (QIAGEN 2003). Nucleic acids were eluted using $80 \mathrm{ml} \mathrm{AE}$ buffer (QIAGEN 2003). DNA obtained from mucus samples was compared with DNA isolated from 20 to $30 \mathrm{mg}$ foot tissue of the same individuals (following the DNeasy protocol of QIAGEN 2003).

The shell of terrestrial snails has two distinct layers: the thick, inner ostracum made mostly of calcium carbonate, and the outer periostracum, which is proteinaceous, horny and transparent. Growing juveniles build first the organic periostracum and then deposit the ostracum. Damages to the newly built, soft periostracum can be repaired within 2-3 weeks. We removed a piece (ca. $0.5 \mathrm{~cm}^{2}$ ) of the newly built, uncalcified periostracum of immature $A$. arbustorum. The samples were transferred in $200 \mu \mathrm{l}$ ATL buffer and nucleic acids were isolated as described above for the mucus samples. The immature snails did not suffer from this treatment. They rebuilt the removed part of the periostracum and continued shell growth as did untreated control snails. After attaining adult size, the individuals were frozen for DNA extraction from foot tissue.

An enriched genomic library was constructed by ECOGENICS GmbH (Zurich, Switzerland), with size-selected genomic DNA, ligation into TSPAD-linker (Tenzer et al. 1999), and magnetic bead selection of biotin-labeled $(\mathrm{CA})_{13}$ motifs 


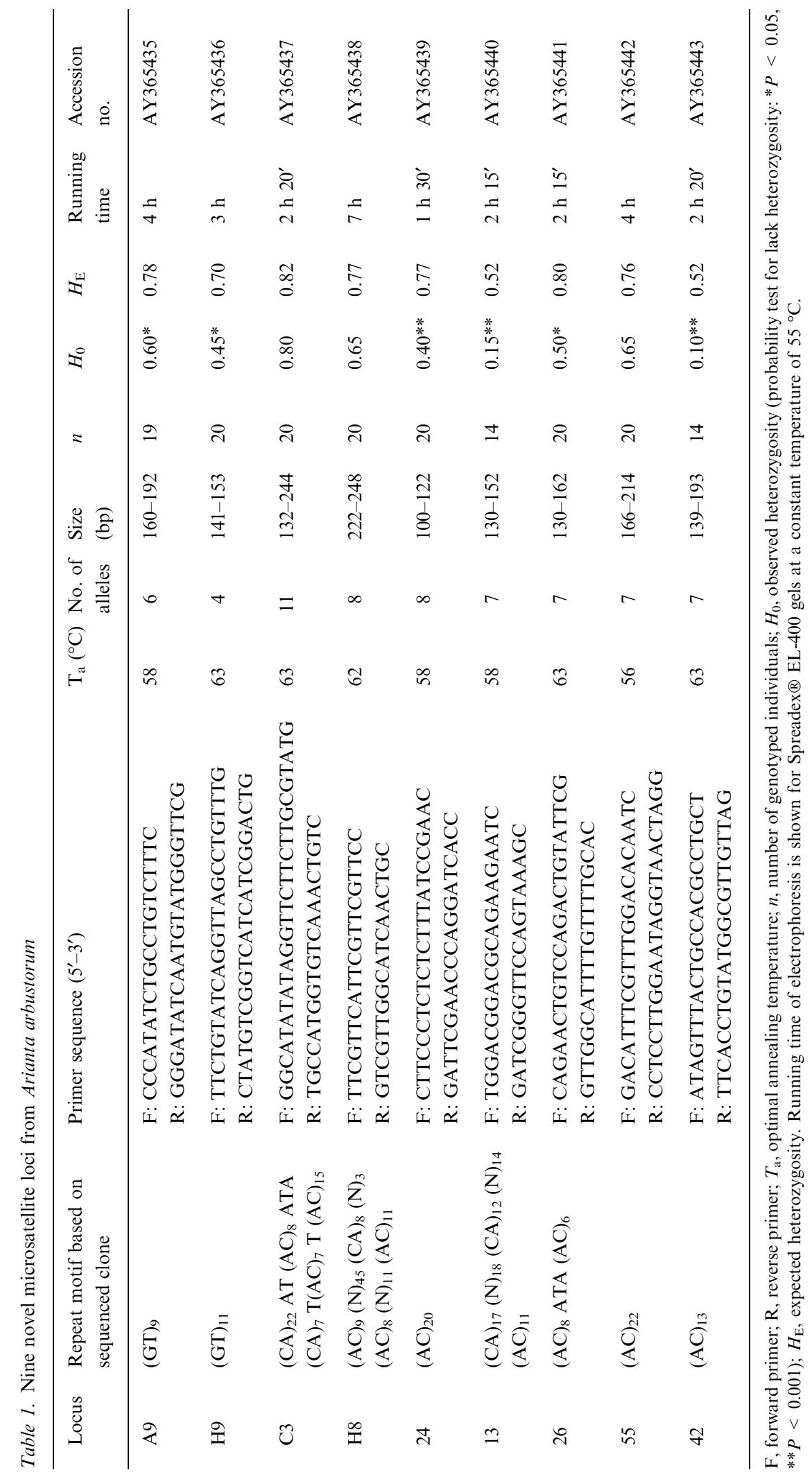


(Gautschi et al. 2000a,b). Of 672 recombinant colonies, 174 gave positive signals after hybridization. Plasmids from 72 positive clones were sequenced and primers were developed for 22 microsatellite inserts. Primers were tested in individuals from Gurnigelbad, Switzerland $(n=19)$ and Tallinn, Northern Estonia $(n=1)$ using standard DNA extraction of frozen foot tissue (QIAGEN 2003). PCR mixture was 10-20 ng of DNA $(2 \mu \mathrm{l}), 0.5 \mu \mathrm{M}$ of each forward and reverse primer, $1.5 \mathrm{mM} \mathrm{MgCl}_{2}$ and $2 \mu \mathrm{l}$ of $10 \mathrm{x}$ PCR buffer, adjusted with $\mathrm{ddH}_{2} 0$ to $20 \mu \mathrm{l}$. PCR was 30-35 cycles, with $95{ }^{\circ} \mathrm{C}$ for $30 \mathrm{sec}$, locus specific annealing for $30 \mathrm{sec}$ (Table 1), and $72^{\circ} \mathrm{C}$ for $30 \mathrm{sec}$. PCR was finished with an extension of 8 min at $72^{\circ} \mathrm{C}$. Spreadex ${ }^{\circledR}$ EL-400 gels (Elchrom Scientific AG, Switzerland) were used. Horizontal electrophoresis was performed with SEA $2000^{\mathrm{TM}}$ advanced submerged gel electrophoresis equipment (Elchrom Scientific AG). All primer pairs gave excellent results, with very few or no stutter bands. A total of 65 alleles were found (Table 1). Of these, eight alleles were exclusively detected in the specimen of Estonia, suggesting geographic differentiation. Six of the tested loci showed a deviation from Hardy-Weinberg equilibrium that could be either the result of null alleles or sampling artifacts (Table 1). Moreover, in pairwise comparison the loci "C3" and "42" showed a trend $(P<0.06)$ for linkage disequilibrium (tested with GENEPOP version 3.1d, see Raymond and Rousset 1995).

All three DNA sources yielded identical allelic patterns (Figure 1). In the comparison of the DNA from the three sources, each $5 \mu \mathrm{AE}$ volume of the mucus and periostracum samples were used for PCR, whilst 10-20 ng DNA (solved in $5 \mu \mathrm{l} \mathrm{ddH}_{2} \mathrm{O}$ ) isolated from the foot tissue was required (see above). However, genotyping errors should be checked before population studies are conducted, because allelic dropouts may occur in non-invasive samples (e.g., Taberlet and Luikart 1999; Parsons 2001; Sefc et al. 2003). The extraction volume of the two foot rubbing samples $(80 \mu 1)$ is sufficient to screen 16 loci (or eight loci twice, or four loci three times; depending on error risk). The amount of DNA from mucus was increased by repeating foot rubbing of the focal snail. The use of these novel sources of DNA need not be limited to A. arbustorum. The non-destructive methods are

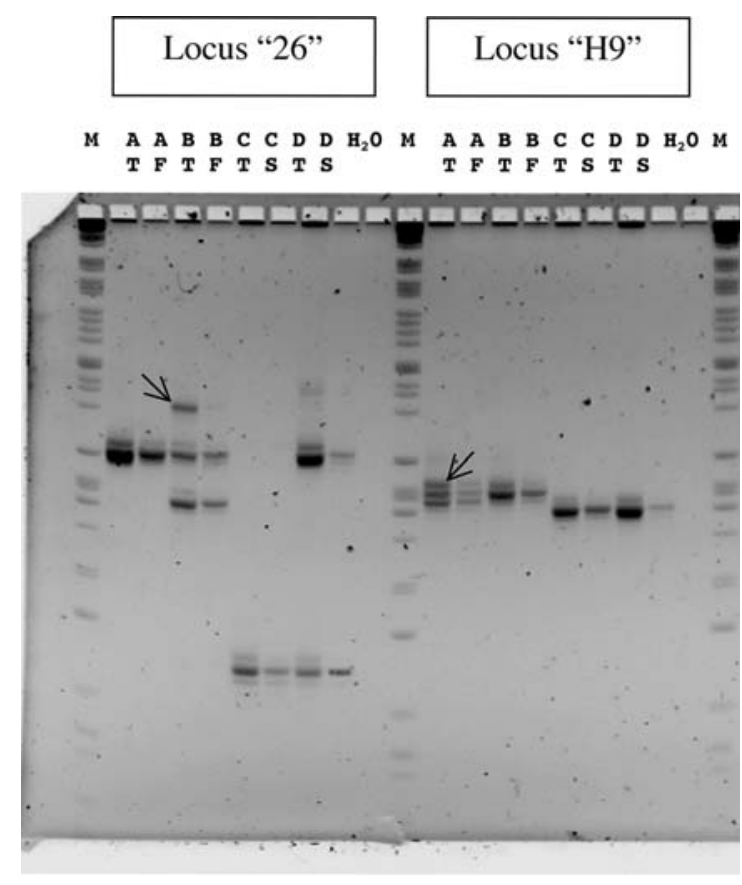

Figure 1. Electrophoretic patterns of locus " 26 " and "H9" in four individuals of $A$. arbustorum (A,B,C,D). Resources of DNA are: T, foot tissue, ca. $20 \mathrm{mg}$; F, foot mucus; S, shell periostracum. Genotypes at " 26 ": $\mathrm{A}=a a, \mathrm{~B}=a b, \mathrm{C}=c c$, $\mathrm{D}=a c$. Genotypes at "H9": $\mathrm{A}=a b, \mathrm{~B}=a a, \mathrm{C}=c c, \mathrm{D}=c c$. Black arrows indicate prominent heteroduplex signals. $\mathrm{M}=$ M3 size marker (Elchrom Scientific AG).

particularly suitable for endangered and rare terrestrial gastropods and may find wider applicability.

\section{Acknowledgement}

Financial support was received from the Swiss National Science Foundation.

\section{References}

Alpers DL, Taylor AC, Sunnucks P, Bellman SA, Sherwin WB (2003) Pooling hair samples to increase DNA yield for PCR. Conserv. Genet., 4, 779-788.

Feinstein J (2004) DNA sequence from butterfly frass and exuviae. Conserv. Genet., 5, 103-104.

Gautschi B, Tenzer I, Müller JP, Schmid B (2000a) Isolation and characterisation of microsatellites in the bearded vulture (Gypaetus barbatus) and cross amplification in three Old World vulture species. Mol. Ecol., 9, 2193-2195.

Gautschi B, Widmer A, Koella J (2000b) Isolation and characterization of microsatellite loci in the dice snake (Natrix tessellata). Mol. Ecol., 9, 2191-2193. 
Hedmark E, Flagstad Ø, Segerström P, Persson J, Landa A, Ellegren H (2004) DNA-based individual and sex identification from wolverine (Gulo gulo) faeces and urine. Conserv. Genet., 5, 405-410.

Idaghdour Y, Broderick D, Korrida (2003) Faeces as a source of DNA for molecular studies in a threatened population of great bustards. Conserv. Genet., 4, 789-792.

Locher R, Baur B (2001) Isolation of microsatellite markers in the hermaphroditic land snail Arianta arbustorum (Gastropoda). Mol. Ecol. Notes, 1, 39-40.

Luchtel DJ, Deyrup-Olson I (2001) Body wall and function. In: The Biology of Terrestrial Molluscs (ed. Barker GM), pp. 147-178. CABI Publishing, Oxon.

Parsons KM (2001) Reliable microsatellite genotyping of dolphin DNA from faeces. Mol. Ecol. Notes, 1, 341-344.

QIAGEN (2003) DNeasy, Tissue Handbook. July 2003. Protocol: Isolation of Total DNA from Animal Tissues, pp. 18-20. QIAGEN AG, Basel, Switzerland.
Raymond M, Rousset F (1995) GENEPOP (version 1.2): population genetics software for exact tests and ecumenicism. J. Hered., 86, 248-249.

Sefc KM, Payne RB, Sorenson MD (2003) Microsatellite amplification from museum feather samples: effects of fragment size and template concentration on genotyping errors. Auk, 120, 982-989.

Taberlet P, Luikart G (1999) Non-invasive genetic sampling and individual identification. Biol. J. Linn. Soc., 68, 41-55.

Tenzer I, degli Ivanissevich S, Morgante M, Gessler C (1999) Identification of microsatellite markers and their application to population genetics of Venturia inaequalis. Phytopathology, 89, 748-753.

Wisely SM, Maldonado JE, Fleischer RC (2004) A technique for sampling ancient DNA that minimizes damage to museum specimens. Conserv. Genet., 5, 105-107. 